\title{
Gold is not for Eating
}

\section{Conflicts Related to Gold Mining in Burkina Faso}

Bettina Engels

Keywords: extractivism, mining, gold, conflict, Africa, Burkina Faso

$\mathrm{R}$ esource extraction, for the last two decades, has been one of the fastest growing economic sectors all over the world and particularly in the Global South. Encouraged by the international financial institutions, many governments promote the extractive sector as a driver for national development. However, resource rich states do not necessarily feature a higher level of economic development than others, nor better living conditions of the population. The extractive sector has significant economic, social, and environmental impacts that are far from being just positive: loss of agricultural land and pasture, scarcity and pollution of surface and ground water, soil degradation, noise, rising cost of living in mining areas impact large parts of societies, and particularly poor and marginalized social groups. In many states of the Global South, mining areas are among the poorest and 'least developed' within the country. Hardly surprisingly, resource extraction, all over the world, is being accompanied by conflicts and the mobilization of civil society actors.

This article presents large-scale gold mining and related conflicts in Burkina Faso-a paramount example of the recent commodity boom and its pervasive socioeconomic effects. Mobilization around the Houndé gold mine, located $250 \mathrm{~km}$ southwest of the capital Ouagadougou, is depicted as an illustration.

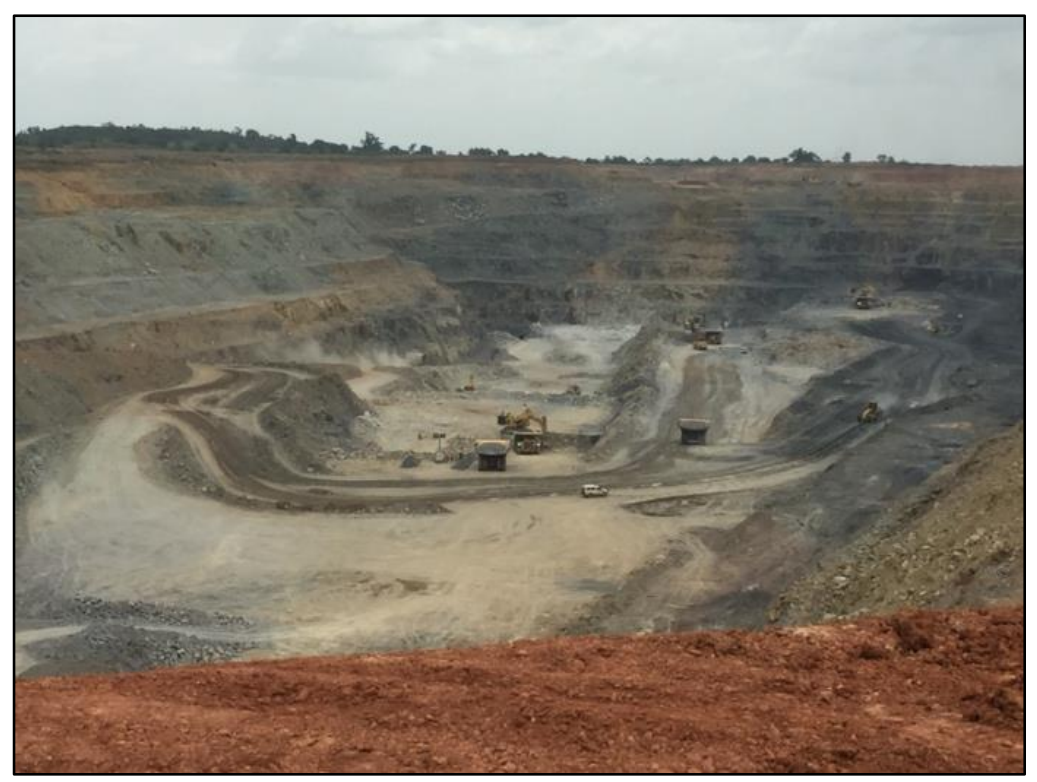

Houndé Gold Mine. Source: Author, 2019.

\section{Correspondence:}

Bettina Engels, bettina.engels@fu-berlin.de.

Cite this article:

Engels, B. 2020. "Gold is not for Eating: Conflicts Related to Gold Mining in Burkina Faso." Commodity Frontiers 1: 1-6. doi: 10.18174/CF.2020a17960.

Commodity Frontiers is an open-access journal edited by the CFI Editorial Board, Mindi Schneider, senior editor. Read it online at Commodity Frontiers, or our website, commodityfrontiers.com.

This work is licensed under a Creative Commons Attribution-NonCommercial 4.0 International License. 


\section{onflicts over gold mining in Burkina Faso}

15 large-scale mines - 14 gold mines and one zinc mine- are currently active in Burkina Faso. All started production in the late 2000s and are run by multinational companies. Burkina Faso's first mining law, the Code Minier, became effective in 1997. It represented a liberalization of the sector, as private economic mining activities were both permitted and encouraged. With the first reform of the Code Minier in 2003, the taxes and tariffs were re-regulated, under the aegis of the World Bank, in order to make the Burkinabé mining industry even more attractive to foreign investors.

Burkina Faso is currently Africa's fifth largest gold producing country (after South Africa, Tanzania, Ghana and Mali). In 2019, 50.3 tons of gold were produced (Kaboré, 2020). Exploration and exploitation permits for industrial mining have been issued for almost half of the surface of the country (OCDE, 2018). Altogether, the industrial mines in Burkina Faso directly employed about 10,000 people, the large majority in low qualified and badly paid positions (Kaboré, 2018). Though the vast majority are Burkinabé, they mostly do not come from the villages directly affected by the mines. Since 2009, gold has been Burkina Faso's most important export product, exceeding cotton. In 2017, the mining sector accounted for 71 per cent of the total export earnings, 16 per cent of tax revenue, and 8.46 per cent of the country's GDP (BDO, 2019, 48-49). The attractiveness of the Burkinabé mining sector for multinational corporations is due, among other factors, to the comparably low taxation by international standards: until 2015, corporate tax for the mining industry was set at 20 per cent, significantly less than in most other African countries (for example, 30 per cent in Sierra Leone and Tanzania, and 35 per cent in Ghana; KPMG, 2017). In 2015, it was adjusted the rate to 25 per cent, which is still relatively low. Worldwide, Burkina Faso is among the top 10 countries for ongoing gold exploration, as measured by the annual budget for gold exploration (World Bank, 2019, 47).

In June 2015, the government passed a reform of the mining law. The new mining code is oriented towards generating state revenues through mining, especially via a newly introduced Mining Fund for Local Development (Fonds Minier de Développement Local, FMDL). In addition to the regular royalties and taxes, mining companies are supposed to pay 1 per cent of their monthly turnover into the fund. Moreover, 20 per cent of the state revenue from the surface tax will be added to the fund. First payments of the Fund to the municipalities were made in 2020; however, most mining companies had not yet paid in the full amount they owe to the Fund. The introduction of the FMDL, was the result of persistent campaigns by Burkinabé civil society organizations, for a more just distribution of the state revenues generated by the mines.

\section{$\mathbf{A}^{\text {rimand niming }}$}

Whereas industrial mining is quite recent in the country, Burkina Faso has a tradition of artisanal gold mining, known as orpaillage, which began long before colonization. Since the 1980s, and particularly related to the recent boom in mining, artisanal mining has likewise increased. Burkina Faso therewith reflects the global trend: almost everywhere in the world where artisanal mining is currently practiced to a significant degree, it has expanded alongside large-scale mining. Whereas according to official statistics, only 3 per cent of the gold produced in Burkina Faso is extracted artisanally, it is estimated that de facto the share is rather 25 per cent (Arnaldi di Balme \& Lanzano, 2014, 18). The recent report of a parliamentary investigation committee assessed the number of artisanal gold mining sites in Burkina Faso to be more than 1,000 (AN, 2016, 2, 24). At least 1.2 million people make their living through artisanal gold mining, plus a considerable number of community members are supported by them (OCDE, 2018; Pokorny, von Lübke, Dayamba, \& 
Dickow, 2019, 26). Despite the fact that artisanal mining is by and large an informal activity, and is undertaken under precarious conditions with high economic and health risks, it nevertheless offers a considerable number of people a livelihood.

Artisanal miners, or orpailleurs, extract gold by digging holes in the ground. Besides those who work in or on the pits, numerous other people-men and women of all ages as well as children and youths-are involved in processing the artisanally mined gold, or in other work and care that is required to keep the sites running (such as the sale of water, food and products for daily needs, as well as other activities). Several thousand people live and work at some of the largest extraction sites, and some sites exist for years or even decades. Internal organisation and labor relations vary depending on the size of the sites and the degree of mechanization (see in detail, Konkobo \& Sawadogo, 2020, 17-21).

Artisanal mining is also frequently practiced near villages, meaning that those involved in artisanal gold mining do not have to live at the extraction sites permanently. Many households live partially from artisanal mining and partially from farming and animal husbandry; for example, some family members are involved in gold mining while others are engaged in subsistence farming, or they mine gold temporarily in the season between seed sowing and harvesting.

The boom of industrial mining in Burkina Faso has direct effects on artisanal mining as a livelihood activity. Given the high number of people living from artisanal mining, the fact that artisanal miners do not have access to compensation, and that in the view of many people - those involved in artisanal mining themselves and others living in the villages where artisanal mining is practicedthat artisanal mining significantly contributes to 'local development', it is hardly astonishing that the elimination of artisanal mining is among the main causes of miningrelated conflicts.

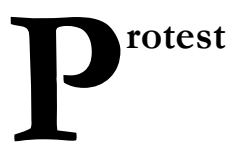

At all mining locations in Burkina Faso, a range of civil society organizations and loosely organized groups of residents engage in protest. People deploy several strategies to raise their claims: addressing the mining companies and local authorities personally and through letters; participating in consultations; as well as more confrontational forms of protest such as riots, demonstrations, marches, sit-ins and blockades. Protests often emerge spontaneously, meaning that they are not directly prepared by formal organizations, though this of course does not mean that there are no structures of social organization behind them. Claims include jobs for workers from the villages in close proximity to the mine, compensation, non-damage of cultural sites such as mosques or graveyards, the approval of artisanal mining, as well as investment in the physical and social infrastructure, e.g. paved roads, schools, and health and women's centers. Moreover, people complain about disrespectful interactions both with the mining companies and public institutions.

Two salient claims are raised frequently: compensation and employment. This is hardly surprising, given that a mine in the neighborhood has a considerable impact on people's income generating possibilities. This does not mean, of course, that within the affected communities no one benefits from the mines. However, in our research, the great majority of interviewees state that for them, the negative impacts of industrial mining by far exceed the potential benefits (Drechsel, Engels, \& Schäfer, 2019; Engels, 2020). The most relevant effect of the expansion of industrial mining, according to the interviewees, is the significant impairment of their livelihood, as they lose their fields and are denied opportunities for artisanal mining. 


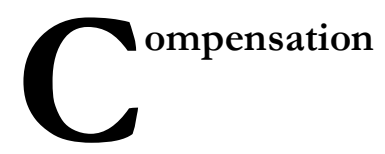

According to the mining code, mining companies have to pay 'just indemnity' to the population affected by their activities, namely land owners and farmers. In 2018, a law on the expropriation of property for public interest was voted in; though until the time of writing in July 2020, only one of the required legal documents that would specify the modalities of the compensation has been adopted, focusing exclusively on the inquiries on public interest and plots. Legal documents on amounts and time periods are still pending, all of which thus remain open to negotiation.

According to international standards (IFC, 2012), a field lost to a mine should be compensated by a new field, as fertile as-or even more so than- the previous one. In Burkina Faso, however, land is virtually always compensated by payments instead of by providing substitute cultivation areas. Generally, farmers receive between 175,000 and 500,000 CFA franc (around 270-765 Euros) per ha per year as compensation, for a period of five years, without renewal, even though the construction and production phase of a mine usually lasts 15 to 20 years. Fields are taken into account for compensation only when they are cultivated in the respective compensation year; this is a problem given that in the farming system of crop rotation, parts of fields are temporarily left fallow.

\section{onflict around the Houndé gold
mine}

A typical example are conflicts related to the Houndé gold mine. Production at the mine started in November 2017, after 18 months of construction. The mine is operated by Houndé Gold Operations, a subsidiary of the Canadian company Endeavour Mining. The Houndé gold mine is the 'company's flagship low-cost mine' (Endeavour Mining, 2017). The mine directly employs 962 persons (Kaboré, 2018). Peasants who lost farmland due to the mine were compensated financially with 350,000 CFA franc (540

Euros) per ha per year for a five-year period. More than 400 households were relocated.

Conflicts particularly concern compensation and employment. In the interviews, people angrily pointed to the fact that the amount of compensation is calculated according to what they used to produce in the respective fields - no matter how many family members had to be fed with it, and regardless of the profit that the mining company makes out of it. Most prominently, they objected to the time limit of the compensatory payments. Limiting the compensatory payment to five years, one resident argued, 'means that they want to reduce the life of these families to five years. They are killing us. We were living from these fields' (Interview, Houndé, 1 March 2018).

People complain that promises made by the company before the granting of the concession (during the mandatory environmental and social impact assessments) have not been upheld, particularly concerning investment in infrastructure, employment opportunities, and income generating measures. According to local civil society organizations, recruiting was non-transparent and nepotistic; even for 'non-qualified' labor and work that could be done by people from the community, staff was recruited from 'elsewhere'. Whereas mining companies refer to Burkinabé nationals as 'local staff, for people from the affected villages, 'local' means the village, district, or province. The Coordination of Professional Associations and the Youth of Tuy province (Coordination des Associations socioprofessionnelles et de la Jeunesse du Tuy, CCJ), a local civil society alliance, complains that only two out of 14 mechanics who were recruited by the Houndé gold mine came from the town itself (CCJ, 2017). The company did provide professional training but then did not employ anyone who had been trained, civil society representatives criticized. As a consequence, they call for a recruitment quota: out of every relocated household, or from every farmer who has 
lost his fields, one child should be employed by the mine (CCJ, 2018).

The CCJ, which was created in 2016, is a broad alliance representing numerous associations of manufacturers, service providers, merchants, horticulturists, stockbreeders, fishermen, artisanal miners, and village assembly representatives. It calls public meetings and press conferences, and meets with state authorities at the national and local level and with the mining company to raise its claims. In its recent memorandum (CCJ, 2018), it joined forces with the labor union of mine workers (Syndicat des Travailleurs de la Géologie, des Mines et Hydrocarbure, SYNTRAGMIH). During marches organized by the alliance (e.g. on 24 February 2017), protestors have faced repression by state security forces. On 23 March 2018, local youths spontaneously blocked the principal road leading to the town and the mine. Only vehicles related to the mine, including the buses transporting workers to the mine, were hindered from passing, while other vehicles could go through. According to activists, the workers agreed in principal: 'They, too, want jobs for their younger brothers' (Interview, Houndé, 1 March 2018). On 17 April 2018, youths marched to claim that the mining company should hire those who have participated in the professional training it has provided. The state security forces stopped the march and arrested five demonstrators.

People feel that the mining companies are neglecting fundamental social rules. This became evident through residents' emphasis on the fact that the companies have not kept their promises, and that they feel overlooked. For instance, residents from a village in close proximity to the Houndé mine reported that when they complained about the fissures that the blasting caused to their houses, the mining company's representative claimed that they had been caused by rainfall. Hardly surprisingly, this incensed the villagers. If the company does not play by the rules, the people will not do so either, they said. 'If it does not come to a showdown, nothing will happen', activists claimed (Interview, Houndé, 18 September 2017).

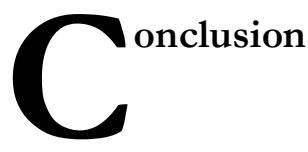

Many people who are affected by the mines perceive the companies' activities and comportment (and related to this, that of the state authorities) as profoundly unjust and illegitimate. A central point in this respect is that the mines take land from the villagers, and hence their base of subsistence, without giving anything appropriate in return so that people can feed their families. Making profit while allowing people to starve is considered illegitimate, and thus fighting against thiswhich includes rule-breaking such as enclosure trespassing - is viewed as just and reasonable.

Where there are winners, inevitably there are loosers, too, at whoses expenses benefits are made. And in the extractive sector, these expenses are considerably. The bulk of the benefits from industrial mining go to the multi-national companies and to some national firms (such as subcontractors and suppliers) and a relatively small number of employees and tradespersons. By way of contrast, there is a significantly larger number of people loosing their base of livelihood and are forcefully resettled.

Conflicts over mining also concern fundamental questions of democracy: The issue at stake is not limited to who gets what and what happens to the benefits; it is likewise a question of who decides on this and how. In the processes of granting a mining concession, the affected population has the right to raise their objections and claims in the mandatory consultations. But a real opportunity to hamper a mining project is hardly provided by most national mining laws. Thus it is hardly astonishing that for many people confrontative means of protest are the only ones that are effective to enforce their interests and claims. 


\section{References}

AN. (2016). Rapport Général de la commission d'enquête parlementaire sur la gestion des titres miniers et la responsabilité sociale des entreprises minières, Septembre 2016. Ouagadougou.

Arnaldi di Balme, L., \& Lanzano, C. (2014). Gouverner l'éphémère. Étude sur l'organisation technique et politique de deux sites d'orpaillage (Bantara et Gombélèdongou, Burkina Faso. Etude Recit nº37.

BDO. (2019). Initiative pour la Transparence dans les Industries Extractives (ITIE) Burkina Faso. Rapport ITIE 2017. Août 2019. Ouagadougou.

CCJ. (2017). Mémorandum des Corps socioprofessionnel et de la Jeunesse du Tuy, Houndé le 11 février 2017. Houndé. CCJ. (2018). Remise de mémorandum conformément à nos échanges du 8 décembre 2017 à Houndé. Lettre au Monsieur le Ministre des mines et des carrières, 22 janvier 2018. Houndé.

Drechsel, F., Engels, B., \& Schäfer, M. (2019). "The mines make us poor”: large-scale mining in Burkina Faso. GLOCON Country Report No. 2. Berlin.

Endeavour Mining. (2017). Endeavour Achieves First Gold Pour at Houndé Abead of Schedule and Below Budget, press release, October 19, 2017 bttps://wmw.endeavourmining.com/news-releases/press-releasedetails/2017/Endeavour-Achieves-First-Gold-Pour-at-Hound-Abead-of-Schedule-and-BelowBudget/default.asp $x$, last access: 3 July 2020.

Engels, B. (2020). All good things come from below? Scalar constructions of the 'local' in conflicts over mining. Political Geography, forthcoming.

IFC. (2012). Performance Standard 5. Land Acquisition and Involuntary Resettlement. Washington D.C.: https://www.ifc.org/wps/wcm/connect/3d82c70049a79073b82cfaa8c6a8312a/PS5 En glish 2012.pdf?MOD=AJPERES

Kaboré, E. (2018). Mine en 2017 : Une valeur budgétaire de plus de 226 milliards de FCFA. Economist du Faso, 30 April 2018(249).

Kaboré, E. (2020). Production minière en 2019: Baisse de la production mais hausse des recettes. Economist du Faso, June 2020, https:// wmw.leconomistedufaso.bf/2020/06/23/production-miniereen-2019-baisse-de-la-production-mais-hausse-des-recettes/.

Konkobo, H. M., \& Sawadogo, I. (2020). Exploitation minière artisanale et semi-mécanisée de l'or an Burkina Faso: Les acteur trices de la chaine opératoire, leur vécu quotidien et leurs perceptions des tentatives actuelles d'encadrement et de formalisation. GLOCON Country Report No. 5. Berlin.

KPMG. (2017). Corporate tax rates tables. https://home.kpmg.com/xx/en/home/services/tax/taxtools-and-resources/tax-rates-online/corporate-tax-rates-table.html

OCDE. (2018). L'or à la croisée des chemins : Étude d'évaluation des chaînes d'approvisionnement en or produit au Burkina Faso, an Mali et au Niger. Paris.

http://mneguidelines.oecd.org/Evaluation-des-chaines-approvisionnement-en-orproduit-au-Burkina-Faso-Mali-Niger.pdf

Pokorny, B., von Lübke, C., Dayamba, S. D., \& Dickow, H. (2019). All the gold for nothing? Impacts of mining on rural livelihoods in Northern Burkina Faso. World Development, 119, 23-39.

World Bank. (2019). Creating Markets in Burkina Faso. Growing Burkina Faso's Pricate Sector and Harnessing it to Bolster Economic Resilience. Washington, D.C.

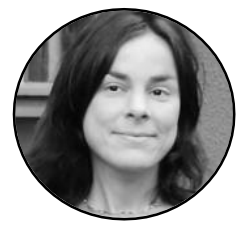

Bettina Engels is Assistant Professor for Conflict and African Studies at Freie Universität Berlin. Together with Kristina Dietz, she is co-director of the research group GLOCON (Global Change - Local Conflict?). The article is based on research conducted in the context of GLOCON since 2015. 